\title{
Larangan Penggunaan Fasilitas Negara Dalam Pemilihan Kepala Daerah Berdasarkan Peraturan Perundang-Undangan
}

\author{
Ardenolis $^{1}$, Sudi Fahmi ${ }^{2}$, Ardiansyah ${ }^{3}$ \\ Pascasarjana Fakultas Hukum Universitas Lancang Kuning \\ Email: arethenolist@gmail.com
}

\begin{abstract}
ABSTRAK
Penyalahgunaan fasilitas negara untuk kepentingan kampanye petahana memang sudah cukup sering terjadi. Dimana para calon petahanan dianggap menggunakan baliho "promo daerah" yang sebenarnya bertujuan untuk mengenalkan daerah tersebut, juga digunakan sebagai alat untuk berkampanye secara terselubung. Terlebih didalam baliho tersebut hanya menonjolkan sosok mereka dibalik program pemerintah daerah dan "promo daerah", sehingga hal tersebut dapat dikatagorikan kedalam kampanye terselubung. Rumusan masalah dalam penelitian ini adalah adalah Larangan Penggunaan Fasilitas Negara Dalam Pemilihan Kepala Daerah Berdasarkan Peraturan Perundang-Undangan Dan Akibat Hukum Terhadap Larangan Penggunaan Fasilitas Negara Dalam Pemilihan Kepala Daerah Berdasarkan Peraturan Perundang-Undangan.Dengan adanya kewenangan tersebut, sangat memungkinkan bagi kepala daerah untuk membujuk, memengaruhi bahkan memerintah para bawahannya untuk berpihak dan memberikan dukungan untuk kepentingan kepala daerah. Akibat hukum dari Larangan Penggunaan Fasilitas Negara Dalam Pemilihan Kepala Daerah Berdasarkan Peraturan Perundang-Undangan bahwa Pasal 187 ayat (3) Undang-Undang No. 1 Tahun 2015 Tentang Pemilihan Kepala Daerah yaitu pidana penjara paling singkat 1 (satu) bulan atau paling lama 6(enam) bulan dan/atau denda paling sedikit Rp 100.000,00 (seratus ribu rupiah) atau paling banyak $\mathrm{Rp}$ 1.000.000,00 (satu juta rupiah), apabila terindikasi melakukan tindak pidana penyelewengan fasilitas negara. Namun banyak yang tidak melaporkan ke ranah hukum akibat tidak adanya sosialisasi dan informasi dari pihak Bawaslu kepada instansi stake holder, yakni KPU, Pemda, Kepolisian dan Satpol PP.
\end{abstract}

Kata Kunci: Fasilitas Negara, Kepala Daerah, Peraturan PerundangUndangan

\section{ABSTRACT}

Misuse of state facilities for the benefit of incumbent campaigns has occurred quite frequently. Where the incumbent candidates are considered to be using "regional promo" billboards which actually aim to introduce the area, it is also used as a tool to campaign in disguise. Moreover, the billboards only highlight their figure behind local government programs and "regional promos", so that these can be categorized into hidden campaigns. The formulation of the problem in this research is the Prohibition of Using State Facilities in Regional Head Elections based on the Legislative Regulations 
and the Legal Consequences on the Prohibition of Using State Facilities in Regional Head Elections based on the Legislation. With this authority, it is possible for regional heads to persuade, influence and even order their subordinates to take sides and provide support for the interests of the regional head. The legal consequence of the prohibition on the use of state facilities in regional head elections is based on the laws and regulations that Article 187 paragraph (3) of Law no. 1 of 2015 concerning Regional Head Elections, namely imprisonment for a minimum of 1 (one) month or a maximum of 6 (six) months and / or a fine of at least IDR 100,000.00 (one hundred thousand rupiah) or a maximum of IDR 1,000,000.00 (one million rupiah), if it is indicated that they have committed a criminal act of misappropriation of state facilities. However, many do not report to the legal realm due to the lack of socialization and information from the Bawaslu to stakeholder agencies, namely the KPU, Regional Government, Police and Satpol PP.

Keywords: State Facilities, Regional Heads, Legislative Regulation

\section{A. PENDAHULUAN}

Larangan soal penggunaan fasilitas negara dalam kampanye diatur dalam Undang-Undang Nomor 7 Tahun 2017 tentang Pemilu. Pasal 304 ayat (1) menyebutkan, dalam melaksanakan kampanye, presiden dan wakil, presiden, pejabat negara, pejabat daerah dilarang menggunakan fasilitas negara. Sementara dalam ayat (2) disebutkan, Fasilitas negara sebagaimana dimaksud pada ayat (1) berupa: sarana mobilitas, seperti kendaraan dinas meliputi kendaraan dinas pejabat negara dan kendaraan dinas pegawai, serta alat transportasi dinas lainnya. ${ }^{1}$ Peraturan Pemerintah Republik Indonesia Nomor 18 Tahun 2013 Tentang Tata Cara Pengunduran Diri Kepala Daerah, Wakil Kepala Daerah, Dan Pegawai Negeri Yang Akan Menjadi Bakal Calon Anggota DPR, DPD, DPRD Provinsi, Dan DPRD Kabupaten/Kota, Serta Pelaksanaan Cuti Pejabat Negara Dalam Kampanye Pemilu Pasal 8 yang mengatakan bahwa Pejabat Negara dalam melaksanakan Kampanye Pemilu tidak menggunakan fasilitas negara kecuali ditentukan lain oleh undang-undang. Lebih lanjut yang dimaksud pejabat Negara diatur dalam Peraturan Pemerintah tersebut pada pasal 1 yang mengatakan bahwa Pejabat Negara adalah Presiden, Wakil Presiden, menteri dan pejabat setingkat

\footnotetext{
${ }^{1}$ Undang-Undang Nomor 7 Tahun 2017 tentang Pemilu
} 
menteri, gubernur, wakil gubernur, bupati, wakil bupati, walikota, dan wakil walikota.

Dalam penjelasan pasal 8 dalam Peraturan Pemerintah tersebut yang dimaksud dengan fasilitas negara adalah sarana dan prasarana yang dibiayai dari anggaran pendapatan dan belanja negara dan/atau anggaran pendapatan dan belanja daerah. Penyalahgunaan fasilitas negara untuk kepentingan kampanye petahana memang sudah cukup sering terjadi. Dimana para calon petahana dianggap menggunakan baliho "promo daerah" yang sebenarnya bertujuan untuk mengenalkan daerah tersebut, juga digunakan sebagai alat untuk berkampanye secara terselubung. Terlebih didalam baliho tersebut hanya menonjolkan sosok mereka dibalik program pemerintah daerah dan "promo daerah", sehingga hal tersebut dapat dikatagorikan kedalam kampanye terselubung. Adapun contoh kasus sebagai berikut :

1. Bawaslu Kabupaten Agam temukan dua petahana gunakan baliho pemda untuk kampanye. $^{2}$ Dua petahana yang menggunakan fasilitas negara tersebut ialah Indra Catri calon Bupati Agam, serta Irwan Fikri calon Bupati Agam. Iklan layanan masyarakat para petahana tersebut saat ini masih terpasang dibeberapa daerah di Kabupaten Agam. Ketua Dewan Kehormatan Penyelenggara Pemilihan Umum (DKPP) Prof. Dr. Jimly Asshiddiqie, S.H. menyatakan "petahana tidak dibolehkan lagi menggunakan fasilitas negara atau ada iklan layanan masyarakat bersumber dari keuangan Negara".

2. Pasangan petahana calon Kepala Daerah Kabupaten Solok Selatan, Sumatera Barat, Muzni Zakaria-Abdul Rahman tidak mengindahkan surat peringatan Komisi Pemilihan Umum (KPU) setempat agar menurunkan Alat Peraga Kampanye (APK) yang mereka pasang. ${ }^{3}$ Walaupun telah dikasi surat peingatan, petahana ini tetap tidak menghiraukan teguran tersebut. Bahkan setelah diberi teguran langsung petahana ini berjanji akan menurunkannya, namun janji itu belum terlaksana.

\footnotetext{
http:/www.gosumbar.com/berita/baca/2015/12/16/panwaslu-agam-temukan-duapetahana-gunakan-balihopemda-untuk-kampanye.html, diakses pada tanggal 25 April 2020 http://www.sumbar.anataranews.com/berita/158197/pasangan-solok-selatan-tidakmengindahkanperingatan.htm, diakses pada tanggal 25 April 2020
} 
Kampanye terselubung penggunaan fasilitas negara memang sulit dipisahkan dengan pelaksanaan tugas sebagai kepala daerah. Namun, kampanye tersebut tetaplah sebuah pelanggaran, dimana terdapat dua pelanggaran dalam kampanye gelap ini, yaitu pelanggaran administratif penggunaan baliho dan penggunaan fasilitas negara untuk kepentingan kampanye. Persoalan ini tentu perlu mendapatkan perhatian dan pengawassan yang serius, demi terciptanya Pemilu yang bersih, jujur dan adil.

Namun masyarakat harus ikut berperan karena kampanye terselubung dan penggunaan fasilitas Negara membuat petahana leluasa melakukannya demi mendapatkan suara terbanyak disaat pelaksanaan Pemilu.

\section{B. METODE PENELITIAN}

Untuk menjelaskan penelitian secara benar dan terarah diperlukan suatu metode penelitian sehingga hasil penelitian dapat digunakan untuk menjawab hasil masalah yang ada dan menganalisis pokok permasalahannya.

\section{Jenis Penelitian Dan Pendekatan Penelitian}

Penelitian yang akan dilakukan penulis bersifat normatif, yaitu penelitian yang berdasarkan pada kaidah hukum yang berlaku, dalam hal ini penelitian dilakukan terhadap dalam Larangan Penggunaan Fasilitas Negara Dalam Pemilihan Kepala Daerah Berdasarkan Peraturan Perundang-Undangan.Jenis penelitian yang digunakan oleh penulis adalah penelitian hukum normatif yaitu penelitian hukum kepustakaan, ${ }^{4}$ karena menjadikan bahan kepustakaan sebagai tumpuan utama. Dalam penelitian hukum normatif ini penulis melakukan penelitian terhadap asas-asas hukum yang bertitik tolak dari bidang-bidang tata hukum tertentu, dengan cara mengadakan identifikasi terlebih dahulu terhadap kaidah-kaidah hukum yang telah dirumuskan di dalam perundang-undangan tertentu. ${ }^{5}$

Jenis penelitian normatif merupakan suatu proses menemukan aturan hukum, prinsip-prinsip hukum, ataupun doktrin-doktrin hukum, untuk menjawab isu hukum yang dihadapi. Hal ini sesuai dengan karakter preskriptif dalam ilmu hukum. Penelitian hukum normatif ini dilakukan untuk menghasilkan

\footnotetext{
${ }^{4}$ Soerjono Soekanto, Sri Mamudji, Penelitian Hukum Normatif, Suatu Tinjauan Singkat, (Jakarta: PT Raja Grafindo, 2003), hlm 23

${ }^{5}$ Ibid. Hlm. 15.
} 
argumentasi, teori atau konsep baru sebagai preskripsi dalam menyelesaikan masalah yang dihadapi. Selanjutnya dijelaskan pula pendekatan penelitian yang digunakan untuk menjawab permasalahan penelitian adalah Pendekatan Peraturan Perundang-undangan (Statute Approach) adalah pendekatan yang digunakan untuk menelaah seluruh peraturan perundang-undangan yang berkaitan dengan permasalahan atau isu hukum yang dihadapi dan juga Pendekatan Kasus (Case Approach) adalah pendekatan yang digunakan untuk menelaah kasus-kasus yang berkaitan dengan isu hukum yang dihadapi. Kasus-kasus yang di telaah merupakan kasus dari putusan pengadilan berkekuatan hukum tetap terkait dengan permasalahan penelitian. ${ }^{6}$

Penelitian hukum normatif bertujuan untuk mempelajari penerapan normanorma dalam praktik hukum terutama mengenai kasus-kasusyang telah diputus sebagaimana yang terdapat dalam yurisprudensi terhadap perkara-perkara yang menjadi focus penelitian

\section{Sumber Data}

Sumber data yang digunakan dalam penelitian hukum normatif ini adalah data sekunder yang dibedakan menjadi 3 (tiga) bagian, yaitu :

a. Bahan Hukum Primer, yakni bahan-bahan ilmu hukum yang berhubungan erat dengan permasalahan yang diteliti, yaitu :

1) Undang-Undang Dasar Negara Republik Indonesia Tahun 1945

2) Undang-Undang Nomor 10 Tahun 2008 Dan Undang-Undang Nomor 7 Tahun 2017 Tentang Pemilu

b. Bahan Hukum Sekunder, yakni bahan-bahan hukum yang memberikan penjelasan atau membahas lebih hal-hal yang telah diteliti pada bahan-bahan hukum primer yang berupa rancangan undang-undang, hasil-hasil penelitian, hasil karya ilmiah dari kalangan ahli hukum, dan sebagainya

c. Bahan Hukum Tertier, yakni bahan-bahan yang memberikan penjelasan terhadap bahan-bahan hukum Primer dan Sekunder, misalnya kamus, ensiklopedi, indeks kumulatif, dan sebagainya

\footnotetext{
6 Pedoman Penulisan Tesis Program Magister Ilmu Hukum Pascasarjana Universitas Lancang Kuning Tahun 2019, hlm 16
} 


\section{Teknik Pengumpulan Data}

Adapun teknik pengumpulan data dalam penelitian hukum normatif hanya digunakan teknik studi documenter/studi kepustakaan, yaitu dengan metode melakukan pengumpulan data-data literature yang terdapat pada kajian kepustakaan yang nantinya akan dikorelasikan dengan permasalahan yang akan diteliti. Dan juga wawancara secara nonstruktur yang berfungsi sebagai penunjang bukan sebagai alat untuk mendapatkan data primer.

\section{Analisis Data}

Data yang dikumpulkan dari bahan hukum primer, sekunder, dan tertier selanjutnya dianalisis secara deskriptif kualitatif. Teknik analisis ini tidak mengunakan angka-angka atau statistik, namun lebih kepada penjelasan dalam bentuk kalimat yang dipaparkan secara lugas. Data yang telah dianalisis dan dideskriptifkan selanjutnya disimpulkan dengan metode deduktif, yakni menyimpulkan dari pernyataan yang bersifat umum ke dalam pernyataan yang bersifat khusus.

\section{Penarikan Kesimpulan}

Penarikan kesimpulan menggunakan logika berpikir deduktif, yaitu penalaran (hukum) yang berlaku umum pada kasus individual dan konkrit (persoalan hukum faktual yang konkrit) yang dihadapi. Proses yang terjadi dalam deduksi adalah konkritisasi (hukum), karena temuan-temuan hukum berupa nilai-nilai, asas-asas, konsep-konsep, dan norma-norma hukum yang dirumuskan secara umum dalam aturan-aturan hukum positif, kemudian dikonkritisasi (dijabarkan) dan diterapkan guna pernyelesaian persoalan hukum konkrit yang dihadapi, sehingga diperoleh kesimpulan sebagai jawaban atas permasalahan hukum yang diajukan sebelumnya. Dimana dalam mendapatkan suatu kesimpulan dimulai dengan melihat faktor-faktor yang nyata dan diakhiri dengan penarikan suatu kesimpulan yang juga merupakan fakta dimana kedua fakta tersebut dijembatani oleh teoriteori.

\section{HASIL DAN PEMBAHASAN}

\section{A. Larangan Penggunaan Fasilitas Negara Dalam Pemilihan Kepala}

\section{Daerah Berdasarkan Peraturan Perundang-Undangan}


Penggunaan fasilitas Negara merupakan modus yang paling sering dilakukan kepala daerah pada saat pelaksanaan pemilihan kepala daerah. Wewenang dan kekuasaan yang melekat pada kepala daerah berpotensi besar digunakan untuk kepentingan kepala daerah dalam memenangkan pemilihan. Dengan adanya kewenangan tersebut, sangat memungkinkan bagi kepala daerah untuk membujuk, memengaruhi bahkan memerintah para bawahannya untuk berpihak dan memberikan dukungan untuk kepentingan kepala daerah. ${ }^{7}$

Selain itu dapat kita temui dalam kunjungan kerja yang dilakukan oleh kepala daerah selalu dibalut dengan upaya penggalangan massa. Untuk dapat mengetahui bahwa kegiatan kunjungan kerja tersebut tanpa maksud tertentu maka indikatornya adalah membuat perbandingan jumlah kunjungan kerja kepala daerah yang merupakan kepala daerah pada saat mendekati pelaksanaan pilkada dengan kunjungan kerja pada tahun-tahun sebelumnya. Jika hasilnya sama, artinya kegiatan tersebut merupakan rutinitas yang selalu dilakukan selama masa kepemimpinannya. Tetapi jika kegiatan tersebut menjelang pemilihan lebih banyak, maka hal tersebut merupakan upaya penggalangan dukungan ataupun pencitraan. $^{8}$

Ada keuntungan tersendiri bagi para kepala daerah seperti yang disebutkan oleh Catherine Needham, mereka bisa melakukan kampanye permanen. Istilah kampanye permanen berarti seorang kepala daerah telah mempersiapkan diri untuk pemilihan jauh hari sebelum lawan-lawannya dengan menggunakan program kerja pemerintah sebagai sarana kampanye secara langsung maupun tidak langsung. Selain itu, satu keunggulan lain yang dimiliki oleh para kepala daerah adalah brand awareness yang tinggi. Brand awareness adalah kemampuan calon pembeli atau konsumen untuk mengenali maupun mengingat sebuah merek. ${ }^{9}$

Disisi lain sebuah riset yang dilakukan oleh The Electoral Research Institute di Belgia menyatakan bahwa yang menjadi kekuatan utama dalam pemenangan

\footnotetext{
7 Rahmat Hollyson MZ dan Sri Sundari, 2015, PILKADA (Penuh euforia, Miskin makna), Bestari: Jakarta, Hal. 38-39

${ }^{8}$ Ibid., Hal. 40

9 Akhmad Farhan, Memahami Kemenangan Petahana Dalam Pilkada Dari Sudut Pandang Political Branding, http://akhmadfarhan.com/memahami-kemenangan-petahana-dalampilkada-dari- sudut-pandang-political-branding/, diakses pada tanggal 5 agustus 2017 pukul 18.00
} 
seorang kandidat bahkan seorang calon incumbent adalah konsolidan sebuah tim sukses (winning coalition), partisipasi politik yang berfokus pada kelompok sasaran pemilih, komunikasi politik yang cukup menarik serta peran penguasaan media dalam proses pemasaran kandidat serta pemasaran sebuah kebijakan. ${ }^{10}$

Pemilihan Kepala Daerah (Pilkada) sebenarnya adalah sarana bagi rakyat daerah untuk mengevaluasi kinerja kepala daerah yang tengah menjabat. Pilkada juga merupakan kesempatan bagi rakyat untuk memberikan hukuman (punishment) bagi pemimpin yang dipandang gagal dengan jalan tidak memilihnya kembali sebagai kepala daerah. Sebaliknya bagi pemimpin yang berhasil, rakyat dapat memberikan ganjaran (reward) berupa dukungan bagi pemimpin itu agar memimpin daerah lima tahun ke depan. Lewat mekanisme demokrasi ini, kepala daerah dituntut untuk meningkatkan kinerja jikalau ingin terpilih kembali. ${ }^{11}$

Hal ini berbeda dengan apa yang ditemukan oleh oleh Hakeem Onapajo dalam jurnal penelitiannya di Nigeria menyimpulkan bahwa kekerasan merupakan strategi yang dimainkan oleh kepala daerah untuk mengintimidasi masyarakat agar menjatuhkan pilihan kepada calon kepala daerah tersebut. Studi ini menunjukkan bahwa kekerasan pemilu merupakan bentuk khusus kekerasan politik. Hal ini karena kekerasan pemilu, terjadi dalam berbagai bentuk pembunuhan, penculikan, pembakaran, penjarahan, mencuri suara dan serangan bersenjata di pusat-pusat pemungutan suara. Secara khas terjadi selama periode pemilu dan terhubung langsung ke proses pemilihan. Hal ini juga terutama menargetkan para pemilih, kandidat, pemantau pemilu, petugas pemilu, dan media. Dalam hal informasi pemilu yaitu: data pendaftaran, pemungutan suara hasil suara, materi kampanye, fasilitas pemilihan (kotak suara, tempat pemungutan suara) dan pada tahapan pemilihan yaitu: kampanye terbuka, latihan pendidikan pemilih, dan latihan penghitungan suara. ${ }^{12}$

10 Bruce Bueno dan Alastair Smith, The Survival Politics (Penerjemah: Budianto Suratno).Rosdakarya: Bandung, 2005, Hal. 32

${ }^{11}$ Fadil Abidin, Peluang Petahana dalam Pilkada, http://fadilabidin75.blogspot.co.id/2013/05/peluang-petahana-dalam-pilkada.html, diakses pada tanggal 5 Agustus 2017

12 Hakeem Onapajo dalam jurnal penelitiannya, Violence and Votes in Nigeria 2007: The Dominance of Incumbents in the Use of Violence to Rig Elections 
Penggunaan kekerasan dalam kegiatan pemilu di Nigeria sangat mencederai sistem demokrasi yang menjunjung tinggi kebebasan, sebagaimana setiap orang mempunyai hak untuk memilih dan bebas untuk memilih siapa kandidatnya. Di Indonesia, penggunaan kekerasan tidak dapat dibenarkan karena bertentangan dengan asas-asas pemilu yang jujur, bersih, bebas dan adil.

Memang, bisa saja kekuasaan diperoleh dengan kekerasan, kemudian, hukum atau norma akan melegitimasi sesudahnya. Namun, kualitas legitimasi itu berpengaruh terhadap ketulusan dukungan warga negara. Kebutuhan akan legitimasi tindakan ini memberi peluang wacana normatif. Orang tidak akan sanggup terus-menerus menghadapi kekerasan dan ketidakpastian. Suatu sistem politik yang rasional, dapat diramalkan dan memperhitungkan manajemen konflik, diperlukan untuk menjamin masa depan yang lebih baik. ${ }^{13}$

Negara modern adalah personifikasi dari tata hukum, artinya bahwa negara dalam segala akifitasnya senantiasa didasarkan pada hukum. Negara dalam konteks ini lazim disebut sebagai negara hukum. Dalam perkembangan pemikiran mengenai negara hukum, dikenal dua kelompok negara hukum, yakni negara hukum formal dan negara hukum materiil. Negara hukum materiil ini dikenal juga dalam istilah Welfarestate atau negara kesejahteraan. Menurut Jimly Asshiddiqie Ide negara kesejahteraan ini merupakan pengaruh dari faham sosialis yang berkembang pada abad ke-19, yang populer pada saat itu sebagai simbol perlawanan terhadap kaum penjajah yang Kapitalis Liberalis. ${ }^{14}$ Dalam perspektif hukum, Wilhelm Lunstedt berpendapat ${ }^{15}$ :

"Law is nothing but the very life of mindkind in organized groups and the condition which make possible peaceful co-existence of masses of individuals and social groups and the coorporation for other ends than more existence and propagation"

Dalam pemahaman ini, Wilhelm Lunstedt nampak menggambarkan bahwa untuk mencapai Social Welfare, yang pertama harus diketahui adalah apa yang mendorong masyarakat yang hidup dalam satu tingkatan peradaban tertentu untuk

8

${ }^{13}$ Haryatmoko, Etika Politik dan Kekuasaan, Penerbit Buku Kompas: Jakarta, 2014, Hal.

14 Soemardi, Teori Umum Hukum dan Negara:Dasar-Dasar Ilmu Hukum Normatif Sebagai Ilmu Hukum Deskriptif-Empirik, Bee Media Indonesia, Bandung, 2010, hlm 225.

${ }^{15}$ Ibid 
mencapai tujuan mereka. Pendapat Lunsteds mengenai social welfare ini hampir sama dengan pendapat Roscou Pound, namun demikian ia ingin menegaskan bahwa secara faktual keinginan sebagian besar manusia yaitu ingin hidup dan mengembangkannya secara layak.

Melihat pandangan mengenai social welfare tersebut, dapat ditarik kesimpulan bahwa bidang social welfare mencakup semangat umum untuk berusaha dengan dalil-dalilnya dan adanya jaminan keamanan, sehingga dapat dibuktikan bahwa ketertiban hukum harus didasarkan pada suatu skala nilai-nilai tertentu, yang tidak dirumuskan dengan rumus-rumus yang mutlak akan tetapi dengan memperhatikan kepentingan-kepentingan masyarakat yang berubah-ubah mengikuti perubahan zaman, keadaan, dan perubahan keyakinan bangsa.

Kunci pokok dalam negara kesejahteraan adalah isu mengenai jaminan kesejahteraan rakyat oleh negara. Mengenai hal ini, Jurgen Habermas berpendapat bahwa jaminan kesejahteraan seluruh rakyat merupakan hal pokok bagi negara modern. Selanjutnya menurut Habermas, jaminan kesejahteraan seluruh rakyat yang dimaksud diwujudkan dalam perlindungan atas The risk of unemployment, accident, ilness, old age, and death of the breadwinner must be covered largely through welfare provisions of the state. ${ }^{16}$ Selanjutnya C.A. Kulp dan John W (dalam Sentanoe Kertonegoro), resiko-resiko tersebut dikategorikan menjadi dua kelompok, yaitu kelompok yang berisiko fundamental dan kelompok berisiko khusus.

Dalam negara kesejahteraan, menurut Sentanoe Kertonegoro, kedua kelompok resiko tersebut harus mendapatkan perhatian untuk diatasi. Alasannya adalah karena resiko fundamental sifatnya adalah makro kolektif dan dirasakan oleh seluruh atau sebagaian besar masyarakat sebagaimana resiko ekonomis. Sedangkan resiko khusus yaitu resiko yang sifatnya lebih kepada makro individual, sehingga dampaknya dirasakan oleh perorangan atau unit usaha ${ }^{17}$.

Dengan demikian, dalam hakekatnya negara kesejahteraan dapat digambarkan keberadaannya sebagai pengaruh dari hasrat manusia yang mengharapkan terjaminnya rasa aman, ketentraman, dan kesejahteraan agar tidak

${ }^{16}$ Gianfranco Poggi, The Development of the Modern State "Sosiological Introduction, California: Standford University Press, 1992, hlm. 126.

${ }^{17}$ Ibid 
jatuh ke dalam kesengsaraan. Alasan tersebut dapat digambarkan sebagai motor penggerak sekaligus tujuan bagi manusia untuk senantiasa mengupayakan berbagai cara demi mencapai kesejahteraan dalam kehidupannya. Sehingga ketika keinginan tersebut telah dijamin dalam konstitusi suatu negara, maka keinginan tersebut harus dijamin dan negara wajib mewujudkan keinginan tersebut. Dalam konteks ini, negara ada dalam tahapan sebaga negara kesejahteraan.

Negara Kesatuan Republik Indonesia juga menganut faham Negara Kesejahteraan. Hal ini ditegaskan oleh para Perintis Kemerdekaan dan para Pendiri Negara Kesatuan Republik Indonesia bahwa negara demokratis yang akan didirikan adalah "Negara Kesejahteraan" (walvaarstaat) bukan "Negara Penjaga Malam" (nachtwachterstaat). Dalam pilihan terkait konsepsi negara kesejahteraan Indonesia ini, Moh. Hatta menggunakan istilah "Negara Pengurus"18. Prinsip Welfare State dalam UUD 1945 dapat ditemukan rinciannya dalam beberapa pasal, terutama yang berkaitan dengan aspek sosial ekonomi.

Dengan masuknya perihal kesejahteraan dalam Undang Undang Dasar Negara Republik Indonesia Tahun 1945, menurut Jimly Asshidiqie Konstitusi Indonesia dapat disebut sebagai konstitusi ekonomi (economic constitution) dan bahkan konstitusi sosial (social constitution) sebagaimana juga terlihat dalam konstitusi Negara Rusia, Bulgaria, Cekoslowakia, Albania, Italia, Belarusia, Iran, Suriah dan Hongaria. Selanjutnya menurut Jimly, sejauh menyangkut corak muatan yang diatur dalam UUD 1945, nampak dipengaruhi oleh corak penulisan konstitusi yang lazim ditemui pada Negara-negara sosialis ${ }^{19}$.

Di dalam UUD 1945, kesejahteraan sosial menjadi judul khusus Bab XIV yang didalamnya memuat pasal 33 tentang sistem perekonomian dan pasal 34 tentang kepedulian negara terhadap kelompok lemah (fakir miskin dan anak telantar) serta sistem jaminan sosial. Ini berarti, kesejahteraan sosial sebenarnya merupakan flatform sistem perekonomian dan sistem sosial di Indonesia. Sehingga, sejatinya Indonesia adalah negara yang menganut faham "Negara Kesejahteraan" (welfare state) dengan model "Negara Kesejahteraan Partisipati

${ }^{18}$ M. Yamin, Naskah Persiapan UUD 1945: Risalah Sidang BPUPKI/PPKI, Sekretariat Negara RI, Jakarta, 1959, hlm. 299.

19 Jimly Asshiddiqie, Hukum Tata Negara dan Pilar-Pilar Demokrasi, Konstitusi Press, Jakarta, 2005, hlm. 124. 
(participatory welfare state) yang dalam literatur pekerjaan sosial dikenal dengan istilah Pluralisme Kesejahteraan atau welfare pluralism. Model ini menekankan bahwa negara harus tetap ambil bagian dalam penanganan masalah sosial dan penyelenggaraan jaminan social (sosial security), meskipun dalam operasionalisasinya tetap melibatkan masyarakat. Sedangkan menurut Mubyarto, Kedua pasal tersebut merupakan suatu hubungan kausalitas yang menjadi dasar disahkannya UUD 1945 oleh para pendiri negara, karena baik buruknya Perekonomian Nasional akan ikut menentukan tinggi rendahnya Kesejahteraan Sosial.

Kepastian hukum dapat kita lihat dari dua sudut, yaitu kepastian dalam hukum itu sendiri dan kepastian karena hukum. Kepastian dalam hukum dimaksudkan bahwa setiap norma hukum itu harus dapat dirumuskan dengan kalimat-kalimat di dalamnya tidak mengandung penafsiran yang berbeda-beda. Akibatnya akan membawa perilaku patuh atau tidak patuh terhadap hukum. Dalam praktek banyak timbul peristiwa-peristiwa hukum, di mana ketika dihadapkan dengan substansi norma hukum yang mengaturnya, kadangkala tidak jelas atau kurang sempurna sehingga timbul penafsiran yang berbeda-beda yang akibatnya akan membawa kepada ketidakpastian hukum.

Teori kepastian hukum merupakan suatu hal yang hanya bisa dijawab secara normatif berdasarkan peraturan perundang-undangan yang berlaku, bukan sosiologis, tapi kepastian hukum secara normatif adalah ketika suatu peraturan dibuat dan diundangkan secara pasti karena mengatur secara jelas dan logis dalam artian tidak menimbulkan keragu-raguan (multi-tafsir) dan logis dalam arti menjadi sistem norma dengan norma yang lain sehingga tidak berbenturan atau menimbulkan konflik norma yang ditimbulkan dari ketidakpastian.

Sedangkan kepastian karena hukum dimaksudkan bahwa karena hukum itu sendirilah adanya kepastian, misalnya hukum menentukan adanya lembaga daluarsa, dengan lewat waktu seseorang akan mendapatkan hak atau kehilangan hak. Berarti hukum dapat menjamin adanya kepastian bagi seseorang dengan lembaga daluarsa akan mendapatkan sesuatu hak tertentu atau akan kehilangan sesuatu hak tertentu. 
Namun demikian, jika hukum diidentikkan dengan perundang-undangan, maka salah satu akibatnya dapat dirasakan adalah kalau ada bidang kehidupan yang belum diatur dalam perundang-undangan, maka dikatakan hukum tertinggal oleh perkembangan masyarakat. Demikian juga kepastian hukum tidak identik dengan dengan kepastian undang-undang. Apabila kepastian hukum diidentikkan dengan kepastian undang-undang, maka dalam proses penegakan hukum dilakukan tanpa memperhatikan kenyataan hukum (Werkelijkheid) yang berlaku

Kepastian hukum merupakan pertanyaan yang hanya bisa dijawab secara normatif, bukan sosiologis. Kepastian hukum secara normatif adalah ketika suatu peraturan dibuat dan diundangkan secara pasti karena mengatur secara jelas dan logis. Jelas dalam artian tidak menimbulkan keragu-raguan (multi-tafsir) dan logis dalam artian ia menjadi suatu sistem norma dengan norma lain sehingga tidak berbenturan atau menimbulkan konflik norma. Konflik norma yang ditimbulkan dari ketidakpastian aturan dapat berbentuk kontestasi norma, reduksi norma atau distorsi norma. ${ }^{20}$

Demokrasi tidak hanya menyelenggarakan pemilu secara berkala, tetapi juga perlu didukung oleh penegakan hak asasi manusia, hukum yang berwibawa, kesadaran politik masyarakat secara luas, dan adanya pergantian kekuasaan secara damai. ${ }^{21}$ Pemilu merupakan media di mana kekuasaan dipertahankan (bagi Incumbent) atau direbut (bagi contender) secara demokratis. Sistem pemilu yang jelas, transparan dan adil (fair) bagi setiap peserta pemilu adalah syarat keharusan (necessary condition). Sementarakedewasaan para peserta pemilu menuju sistem demokrasi modern adalah syarat kecukupan (sufficient condition). Tanpa adanya kedua hal ini maka pemilu hanya akan menghasilkan pemenang tanpa legitimasi. ${ }^{22}$

Memang sistem pemilu dapat dijalankan dengan jelas, transparan dan adil. Namun tanpa adanya kedewasaan peserta pemilu maka hanya akan menghasilkan pemilu yang berakhir dengan konflik. Jika pemilu dijalankan hanya bermodalkan kedewasaan peserta pemilu maka pemilu yang dihasilkan adalah pemenang tanpa legitimasi dan cacat secara hukum. Penggunaan kekerasan pemilu pada masa reformasi di Indonesia tidak akan dibenarkan, karena masyarakat akan bertindak

\footnotetext{
${ }^{20}$ Ibid

${ }^{21}$ Firmanzah, Marketing Politik, Yayasan Pustaka Obor Indonesia: Jakarta, 2013, Hal. xi

${ }^{22}$ Ibid., Hal. XXII
} 
dan Negara melalui aparat keamanan tidak akan tinggal diam untuk membendung kekerasan yang digunakan kepala daerah.

Berdasarakan beberapa penelitian terdahulu yang telah disampaikan diatas, pada kenyataannya calon kepala daerah memiliki banyak keuntungan dibandingkan calon pendatang baru. Namun dalam parkteknya seringkali kepala daerah salah menggunakan kewenangannya untuk mengamankan kedudukannya pada pilkada berikutnya. Selain itu tindakan kekerasan yang dilakukan oleh kepala daerah turut menciderai prinsip demokrasi itu sendiri.

Kinerja Bawaslu sebagai pengawas penggunaan fasilitas oleh calon kepala daerah pada kenyataannya dewasa ini baru sampai tingkat badan yang menjadi tempat melapornya para pelapor dugaan terkait penyelewengan penggunaan fasilitas negara. Pelaporan tersebut juga masih bernuansa politis, dalam artian sebagai salah satu upaya untuk menjegal calon petahana oleh calon Kepala Daerah yang lain. Adanya independensi masyarakat untuk melaporkan dugaan penyelewengan penggunaan fasilitas negara juga masih belum dalam konteks sebagai pengawas yang mandiri, yakni tidak adanya unsur kepentingan dalam pelaporan tersebut. Untuk itu Bawaslu juga harus menjaga independesi masyarakat dalam melaksanakan tugasnya sebagai pengawas pemilu sebagai bentuk nyata partisipasi politik masyarakat untuk mewujudkan pemilihan Kepala Daerah yang demokratis.

Pemilihan Kepala Daerah, sesuai dengan pasal 18 ayat (4) Undang-Undang Dasar 1945 dipilih secara demokratis. Dengan adanya perangkat penyelenggara pemilihan umum seperti KPU, Bawaslu dan DKPP, diharapkan penyelenggaraan pemilukada dapat berjalan secara demokratis sesuai yang diamanatkan konstitusi. Pada dasarnya, pembagian tugas dan kewenangan penyelenggara pemilu harus sudah selesai pembahasannya di tingkat KPU, Bawaslu dan DKPP. Untuk pelaporan terkait pelanggaran administratif, dapat dilaporkan kepada KPU dan Bawaslu.Untuk pelaporan pelanggaran kode etik pemilu, dapat dilaporkan kepada Bawaslu dan DKPP.Untuk pelanggaran berupa tindak pidana pemilu dapat dilaporkan kepada Bawaslu kemudian diteruskan ke Kepolisian. Maka dapat dilihat Bawaslu sebagai media pelaporan dugaan pelanggaran harus disetarakan dan ditingkatkan kewenangannya. Terkait dengan penggunaan fasilitas negara, 
Bawaslu mempunyai tugas dan kewenangan yang lebih besar, walaupun secara peraturan perundang-undangan Bawaslu hanya berhak merekomendasikan terkait putusan sanksi pelanggar jika terbukti oleh KPU.Namun ditinjau dari segi fungsi, Bawaslu mempunyai kewenangan lebih besar, sebagai pengawas penyelenggaraan pemilu sehingga menciptakan aura pemilukada secara demokratis.

\section{B. Akibat Hukum Dari Larangan Penggunaan Fasilitas Negara Dalam Pemilihan Kepala Daerah Berdasarkan Peraturan Perundang-Undangan}

Sistem negara hukum telah masuk ke Indonesia sejak dalam perancangan UUD 1945 dengan dicantumkan istilah rechtsstaat dalam penjelasan umum UUD 1945. Namun setelah amandemen UUD 1945 nampaknya indonesia tidak lagi sekedar menganut sistem negara hukum rechtsstaat akan tetapi juga menganut beberapa prinsip dalam rule of law dan sistem hukum lainnya dengan inti filosofi masing-masing konsep kemudian digabungkan sebagai paradigma negara hukum pancasila. Paradigma ini merajut nilai-nilai baik semua sistem hukum secara eksplisit sehingga menjadi hukum nasional Indonesia. ${ }^{23}$

Indonesia sebagai negara hukum diatur berdasarkan Pasal 1 ayat (3) UUD Negara Republik Indonesia 1945 yang menyebutkan "Negara Indonesia adalah negara hukum" 24 yang menganut sistem desentralisasi dengan menjadikan undang-undang sebagai aturan main. Penjelasan bahwa undang-undang adalah aturan main dalam pemerintahan Indonesia dijelaskan dalam Pasal 18 ayat (1) UUD Negara Republik Indonesia tahun 1945, "Negara Kesatuan Republik Indonesia dibagi atas daerah-daerah provinsi dan daerah provinsi itu dibagi atas kabupaten dan kota, yang tiap-tiap provinsi, kabupaten, dan kota mempunyai pemerintah daerah, yang diatur dengan undang-undang". ${ }^{25}$ Demikian segala urusan pemerintah dari pusat sampai dengan daerah haruslah berdasarkan pada hukum yang berlaku

23 Moh. Mahfud MD, Konstitusi dan Hukum dalam Kontroversi Isu, (Jakarta: PT. Rajagrafindo Persada, 2012), hlm 94

${ }^{24}$ Pasal 1 Ayat (3) Undang-Undang Dasar Negara Kesatuan Republik Indonesia Tahun 1945

${ }^{25}$ Pasal 18 Ayat (1) Undang-Undang Dasar Negara Kesatuan Republik Indonesia Tahun 1945 
Immanuel Kant dalam teori Negara Hukum / Theory State of Law (17241904) menyatakan bahwa negara bertujuan untuk melindungi hak asasi dan kewajiban warga $\mathrm{Negara}^{26}$. Hak asasi memberikan kekuatan moral untuk menjamin dan melindungi martabat manusia berdasarkan hukum, bukan atas dasar kehendak, keadaan, ataupun kecenderungan politik tertentu ${ }^{27}$.

Deklarasi Hak-hak Asasi Manusia bagi negara Indonesia telah ada dari jaman dahulu namun baru di ikrarkan pada pedoman dasar negara ini yaitu yang berada di dalam pembukaan Undang- Undang Dasar 1945 yang di dalamnya terdapat hak-hak asasi selaku manusia baik manusia selaku mahluk pribadi maupun sebagai mahluk sosial yang di dalam kehidupannya itu semua menjadi sesuatu yang inheren, serta dipertegas dalam Pancasila dari sila pertama hingga sila kelima, Jika dilihat dari terbentuknya deklarasi Hak Asasi Manusia bangsa Indonesia lebih dahulu terbentuk dari pada Hak-Hak Asasi Manusia PBB yang baru terbentuk pada tahun $1948^{28}$.

Pasal 1 ayat (3) UUD 1945 menyebutkan bahwa "Negara Indonesia adalah negara hukum“ Negara hukum adalah negara yang menegakkan supermasi hukum untuk menegakkan kebenaran dan keadilan dan tidak ada kekuasaan yang tidak dipertanggung jawabkan.

Berdasarkan uraian di atas yang dimaksud dengan Negara Hukum ialah negara berdiri di atas hukum yang menjamin keadilan kepada warga negaranya. Keadilian merupakan syarat bagi terciptanya kebahagiaan hidup untuk warga negaranya, dan sebagai dasar dari pada keadilan itu perlu diajarkan rasa susila kepada setiap manusia agar ia menjadi warga negara yang baik. Demikian pula peraturan hukum itu mencerminkan keadilan bagi pergaulan bagi hidup antar warga negaranya ${ }^{29}$.

Salah satunya adalah penggunaan fasilitas negara seperti baliho, mobil dinas dan lain-lain yang dilakukan dalam pemilihan Kepala Daerah tingkat Provinsi

${ }^{26}$ Immanuel Kant dalam Muhammad Tahir Azhary, Negara Hukum, PT. Bulan Bintang, Jakarta, 1992, hlm.18.

27 Go Lisanawati, Pendidikan Tentang Pencegahan Kekerasan Terhadap Perempuan Dalam Dimensi Kejahatan Siber, Jurnal Ilmu Hukum Pandecta Vol.9 No.1 Januari, 2014., hlm.5.

${ }^{28}$ Bambang Heri Supriyanto, Penegakan Hukum Mengenai Hak Asasi Manusia (HAM) Menurut Hukum Positif di Indonesia, Jurnal AL-AZHAR INDONESIA SERI PRANATA SOSIAL, Vol . 2, No. 3, Maret 2014.

2929 Moh. Kusnardi dan Harmaily Ibrahim, Pengantar Hukum Tata Negara Indonesia, Pusat Studi Hukum Tata Negara Fakultas Hukum Universitas Indonesia, Jakarta, 1988, hlm. 153. 
maupun tingkat Kabupaten / Kota. Menurut Pasal 187 ayat (3) Undang-Undang No. 1 Tahun 2015 Tentang Pemilihan Kepala Daerah yaitu pidana penjara paling singkat 1 (satu) bulan atau paling lama 6(enam) bulan dan/atau denda paling sedikit Rp 100.000,00 (seratus ribu rupiah) atau paling banyak Rp 1.000.000,00 (satu juta rupiah), apabila terindikasi melakukan tindak pidana penyelewengan fasilitas negara. Namun banyak yang tidak melaporkan ke ranah hukum akibat tidak adanya sosialisasi dan informasi dari pihak Bawaslu kepada instansi stake holder, yakni KPU, Pemda, Kepolisian dan Satpol PP. Hal itu dikarenakan kurangnya biaya akomodasi terkait pelaksanaan pengawasan penggunaan fasilitas negara. Artinya, Bawaslu hanya sekedar menginfokan dan mensosialisasikan secara sepihak, tanpa adanya koordinasi dengan stake holder terkait bentuk pengawasan tersebut kepada masyarakat. Sosialisasi yang dikerjakan oleh Bawaslu juga terkendala akibat adanya saling tumpang tindih antara kewenangan KPU dan DKPP. Bawaslu sebagai salah satu perangkat pemilu masih dianggap kalah pamor dalam segi kewenangan dibandingkan KPU dan DKPP. Padahal, apabila anggota Bawaslu dapat memaksimalkan kinerjanya sesuai dengan peraturan perundang-undangan yang berlaku, bisa jadi kedepannya peraturan khusus mengenai pemilu dan posisi Bawaslu dapat diamanatkan langsung melalui undang-undang maupun peraturan pemerintah. Namun agaknya hal ini harus selaras dalam konteks pemilukada, antara Bawaslu-Bawaslu antar daerah Provinsi sehingga dapat memunculkan animo pada masyarakat bahwa Bawaslu juga mempunyai peran yang dominan dalam pelaksanaan pemilu. Hal ini bukan hanya dalam segi penerimaan laporan tapi juga diberikan kewenangan tambahan untuk langsung menghasilkan keputusan, bukan hanya sekedar rekomendasi. Bawaslu Sumatera Barat dapat menjadi pattern terkait Bawaslu-Bawaslu lain tingkat Provinsi dalam mengerjakan hal tersebut, dimulai dari keefektivan kerja Bawaslu Sumatera Barat dalam konteks pengawasan dugaan pelanggaran administratif berupa penggunaan fasilitas negara. Dalam melakukan pengawasannya, Bawaslu juga terkendala masalah personel yang terjun ke lapangan demi menertibkan para penyeleweng penggunaan fasilitas negara. Personel tersebut terkendala dikarenakan tidak adanya jaminan dan perlindungan hukum terkait dengan bentuk tindak lanjut dari pengawasan Bawaslu tadi. Oleh karena itu, masalah personel ini 
juga menjadi salah satu faktor penghambat Bawaslu terkendala dalam menjalankan tugasnya.

\section{PENUTUP}

\section{Kesimpulan}

Adapun kesimpulan yang dapat diambil dari hasil penelitian yang telah dilakukan oleh penulis antara lain:

1. Larangan Penggunaan Fasilitas Negara Dalam Pemilihan Kepala Daerah Berdasarkan Peraturan Perundang-Undangan bahwa Penggunaan fasilitas Negara merupakan modus yang paling sering dilakukan kepala daerah pada saat pelaksanaan pemilihan kepala daerah. Wewenang dan kekuasaan yang melekat pada kepala daerah berpotensi besar digunakan untuk kepentingan kepala daerah dalam memenangkan pemilihan. Dengan adanya kewenangan tersebut, sangat memungkinkan bagi kepala daerah untuk membujuk, memengaruhi bahkan memerintah para bawahannya untuk berpihak dan memberikan dukungan untuk kepentingan kepala daerah

2. Akibat hukum dari Larangan Penggunaan Fasilitas Negara Dalam Pemilihan Kepala Daerah Berdasarkan Peraturan Perundang-Undangan bahwa Pasal 187 ayat (3) Undang-Undang No. 1 Tahun 2015 Tentang Pemilihan Kepala Daerah yaitu pidana penjara paling singkat 1 (satu) bulan atau paling lama 6(enam) bulan dan/atau denda paling sedikit $\mathrm{Rp} 100.000,00$ (seratus ribu rupiah) atau paling banyak $\mathrm{Rp} 1.000 .000,00$ (satu juta rupiah), apabila terindikasi melakukan tindak pidana penyelewengan fasilitas negara. Namun banyak yang tidak melaporkan ke ranah hukum akibat tidak adanya sosialisasi dan informasi dari pihak Bawaslu kepada instansi stake holder, yakni KPU, Pemda, Kepolisian dan Satpol PP.

\section{Saran}

Adapun saran yang diberikan oleh penulis setelah melakukan penelitian antara lain:

1. Sebaiknya koordinasi antar stake holders untuk menegakan larangan fasilitas negara oleh kepala daerah dalam pemilihan umum 
2. Diperlukan upaya tegas dalam menegakkan Larangan Penggunaan Fasilitas Negara Dalam Pemilihan Kepala Daerah Berdasarkan Peraturan PerundangUndangan

\section{DAFTAR PUSTAKA}

Bambang Heri Supriyanto, Penegakan Hukum Mengenai Hak Asasi Manusia (HAM) Menurut Hukum Positif di Indonesia, Jurnal Al-Azhar Indonesia Seri Pranata Sosial, Vol . 2, No. 3, Maret 2014.

Bruce Bueno dan Alastair Smith, The Survival Politics (Penerjemah: Budianto Suratno).Rosdakarya: Bandung, 2005.

Fadil Abidin, Peluang Petahana dalam Pilkada, http://fadilabidin75.blogspot.co.id/2013/05/peluang-petahana-dalampilkada.html, diakses pada tanggal 5 Agustus 2017.

Firmanzah, Marketing Politik, Yayasan Pustaka Obor Indonesia: Jakarta, 2013.

Gianfranco Poggi, The Development of the Modern State "Sosiological Introduction, California: Standford University Press, 1992.

Go Lisanawati, Pendidikan Tentang Pencegahan Kekerasan Terhadap Perempuan Dalam Dimensi Kejahatan Siber, Jurnal Ilmu Hukum Pandecta Vol.9 No.1 Januari, 2014.

Hakeem Onapajo dalam jurnal penelitiannya, Violence and Votes in Nigeria 2007: The Dominance of Incumbents in the Use of Violence to Rig Elections.

Haryatmoko, Etika Politik dan Kekuasaan, Penerbit Buku Kompas: Jakarta, 2014. http://www.sumbar.anataranews.com/berita/158197/pasangan-solok-selatan-tidakmengindahkanperingatan.htm, diakses pada tanggal 25 April 2020. http:/www.gosumbar.com/berita/baca/2015/12/16/panwaslu-agam-temukan-dua-

petahana-gunakan-balihopemda-untuk-kampanye.html, diakses pada tanggal 25 April 2020.

Immanuel Kant dalam Muhammad Tahir Azhary, 1992, Negara Hukum, PT. Bulan Bintang, Jakarta.

Jimly Asshiddiqie, 2005, Hukum Tata Negara dan Pilar-Pilar Demokrasi, Konstitusi Press, Jakarta. 
M. Yamin, 1959, Naskah Persiapan UUD 1945: Risalah Sidang BPUPKI/PPKI, Sekretariat Negara RI, Jakarta.

Moh. Kusnardi dan Harmaily Ibrahim, Pengantar Hukum Tata Negara Indonesia, Pusat Studi Hukum Tata Negara Fakultas Hukum Universitas Indonesia, Jakarta, 1988.

Moh. Mahfud MD, 2012, Konstitusi dan Hukum dalam Kontroversi Isu, (Jakarta: PT. Rajagrafindo Persada.

Pedoman Penulisan Tesis Program Magister Ilmu Hukum Pascasarjana Universitas Lancang Kuning Tahun 2019.

Rahmat Hollyson MZ dan Sri Sundari, 2015, PILKADA (Penuh euforia, Miskin makna), Bestari: Jakarta.

Soemardi, Teori Umum Hukum dan Negara:Dasar-Dasar Ilmu Hukum Normatif Sebagai Ilmu Hukum Deskriptif-Empirik, Bee Media Indonesia, Bandung, 2010.

Soerjono Soekanto, Sri Mamudji, 2003, Penelitian Hukum Normatif, Suatu Tinjauan Singkat, Jakarta: PT Raja Grafindo, 2003.

Undang-Undang Dasar Negara Kesatuan Republik Indonesia Tahun 1945.

Undang-Undang Nomor 7 Tahun 2017 tentang Pemilu. 